\title{
GROWTH RATE AND CLIMATIC RESPONSE OF MACHAERIUM SCLEROXYLON IN A DRY TROPICAL FOREST IN SOUTHEASTERN SANTA CRUZ, BOLIVIA
}

\author{
K. PAREDES-VIllanUeVA ${ }^{1 *}$, R. SÁNCHEZ-SAlGUERO ${ }^{2}$, R. D. MANZANEDO ${ }^{3}$, R. QUEVEDO SOPEPI ${ }^{1}$, \\ G. PALACIOS ${ }^{3}$, and R. M. NAVARRO-CERRILLO ${ }^{3}$ \\ ${ }^{1}$ Carrera de Ingeniería Forestal, Laboratorio de Dendrocronología, Facultad de Ciencias Agrícolas, Universidad Autónoma \\ Gabriel René Moreno, Km 6 carretera al Norte, El Vallecito Santa Cruz, Bolivia \\ ${ }^{2}$ Centro de Investigación Forestal (CIFOR)-I.N.I.A., Dpto. Ecología y Genética Forestal, Carretera de la Coruña Km 7.5, \\ 28040 Madrid, Spain \\ ${ }^{3}$ Dpto. Ingeniería Forestal, Laboratorio de Dendrocronología, Universidad de Córdoba, Campus de Rabanales, Ctra. \\ N-IV, Km 396, 14071 Córdoba, Spain
}

\begin{abstract}
Machaerium scleroxylon (morado) is an important timber species from the lowland tropical dry forests in Bolivia. We followed a dendrochronological approach to (i) evaluate the responses of radial growth to climatic variables and atmospheric circulation patterns, and (ii) quantify the growth rate in order to estimate the Minimum Logging Diameter (MLD), age, and optimal cutting rotation. We measured tree-ring width in wood discs taken from ten randomly selected mature individuals. We used previous histological analyses to distinguish and visually crossdate tree rings. Despite the existence of false rings, lenses and wedging rings, the species showed defined annual ring boundaries, thus enabling a tree-ring chronology analysis. Correlations between residual ring-width indices and monthly climatic variables (temperature and rainfall) and atmospheric circulation patterns (El Niño-Southern Oscillation) index were calculated. Growth showed a significant positive correlation with monthly rainfall and a negative correlation with mean temperature during the late rainy season (i.e. from December up to March). A positive correlation found between the ring width and ENSO indices indicates that the growth of $M$. scleroxylon was significantly affected by atmospheric circulation patterns. Growth rate is slow in morado, suggesting a MLD of $50 \mathrm{~cm}$ and an optimal cutting cycle longer than 40 years depending on each site.
\end{abstract}

Keywords: tree rings, Machaerium scleroxylon, tropical dendrochronology, El Niño-Southern Oscillation, Minimum Logging Diameter.

\section{INTRODUCTION}

Historical management in tropical forests has shown a general trend towards the adoption of polycyclic selective logging systems. In such systems, harvesting operations are the first and most important silvicultural treatment applied. For this reason, special attention has been given on how to improve harvesting operations for commercial species, mainly based on the Minimum Logging Diameter (MLD; García-Fernández et al. 2007). Unfortunately, MLD values

\footnotetext{
*Corresponding author: E-mail: kathypavi@gmail.com; Telephone: (+591) 70011588; Fax: (+591 - 3) 3434363
}

adopted in Bolivian forestry law are based on arbitrary assumptions of growth rather than profound ecological knowledge. However, understanding the ecological dynamics of the target species is essential to establish truly sustainable management policies in tropical forests.

Tropical dry forests in the lowlands of Bolivia, also known as Chiquitano forest, are among the most diverse in the world (Parker et al. 1993) and occupy an area of approximately 20 million hectares. Forests in Chiquitanía have very low diameter growth rates, with an overall average of $0.173 \mathrm{~cm}_{\text {year }}{ }^{-1}$, ranging from $0.143 \mathrm{~cm}$ year ${ }^{-1}$ to $0.211 \mathrm{~cm} \mathrm{year}^{-1}$ (Dauber et al. 2003). These 
forests are fragile because of slow regeneration capacity under drought conditions, the continuing threat of deforestation, and human-made fires that eliminate forest cover for agriculture and livestock (Uslar et al. 2003). The high vulnerability of tropical dry forest to weather and climate hazards, associated with the history of forestry, make this one of the regions where potential changes in the hydrological cycle caused by global warming could lead to extreme impacts on ecosystems (Toledo et al. 2011).

The behavior of Bolivian forests under climate change conditions can be understood from the study of tree rings. This type of study contributes to closing information gaps about the behavior of forest species and reconstructing historical growth patterns during the entire life of trees (Brienen 2005; Ferrero and Villalba 2009). Similarly, tree-ring characteristics (width and density) reveal details of the natural history of an individual and its ecosystem (Jagels et al. 1994; Pumijumnong and Park 1999). For example, diseases attacks, pests, prolonged drought stress, and damage by fire can be detailed in ring characteristics (Shortle et al. 1995; Weber 1997).

Previous tree-ring studies have been used to analyze the growth dynamics in tropical forests (Worbes 1992; Pumijumnong and Park 1999; Tomazello and da Silva Cardoso 1999), construct tree-ring chronologies in young individuals (SolizGamboa et al. 2011), and evaluate growth patterns related to variation in age (Brienen and Zuidema 2006a; Rozendaal 2010). Tree rings have also supported the determination of MLD (Brienen and Zuidema 2006b; Rozendaal 2010; López et al. 2013) and climate-related growth of several species (Wimmer 2002; Brienen and Zuidema 2005; Ferrero and Villalba 2009; López and Villalba 2011).

Dendrochronology can aid in modeling growth to predict the availability and potential of each species in a future climate scenario and secondary effects on forest management. The phases of growth and relative inactivity in many plants are closely related to environmental factors, e.g. water availability effect on the seasonal cambial activity (Borchert 1994). Thus, knowledge of the relationship between environmental variables and tree growth is important in predicting future growth responses to climatic variation
(Pumijumnong 1999) and to long-term phenomena such as El Niño Southern Oscillation (ENSO) (Cook 1992). Such knowledge will be useful in understanding the behavior of fragile Bolivian ecosystems in a context of global climate change, which can provide guidelines to a suitable forest management (Stahle et al. 1999; Brienen and Zuidema 2005).

Previous studies in species such as Bertholletia excelsa, Cedrelinga catenaeformis, Centrolobium microchaete, Tachigali vaquezii and Peltogine cf. heterophylla (Brienen and Zuidema 2006a, 2006b; López and Villalba 2011) have shown the dendroclimatic potential of several tree species in Bolivia, illustrating that these species develop visible annual rings (Brienen and Zuidema 2005). It is important to study other useful unexplored species such as Machaerium scleroxylon (hereafter referred to as morado), whose population has declined considerably in recent years. In Bolivia, species considered valuable in the main trade group, including morado (Justiniano and Fredericksen 1998), are scarce, with values of basal area and volumes that remain low and often absent in diameter classes above the MLD established in 1996 by the Bolivian Forestry Law No. 1700.

The present study had the following objectives: (i) to develop the first chronology from $M$. scleroxylon, one of the most valuable and fragile timber species from the Chiquitano forest in Santa Cruz de la Sierra, Bolivia, (ii) to quantify the changes in recent radial growth in response to climatic variables such as rainfall, temperature and atmospheric circulation patterns (El NiñoSouthern Oscillation), and (iii) estimate growth rate, MLD and optimal cutting rotation based on age and cumulative ring-width data as input for decision-making to improve forestry and sustainable use of the species. Dendrochronological methods were used to evaluate the response of morado growth to climate and its management implications.

\section{MATERIALS AND METHODS}

\section{Study Site and Climate Data}

The study site is located in the southeastern part of Santa Cruz, Bolivia. This area belongs to 


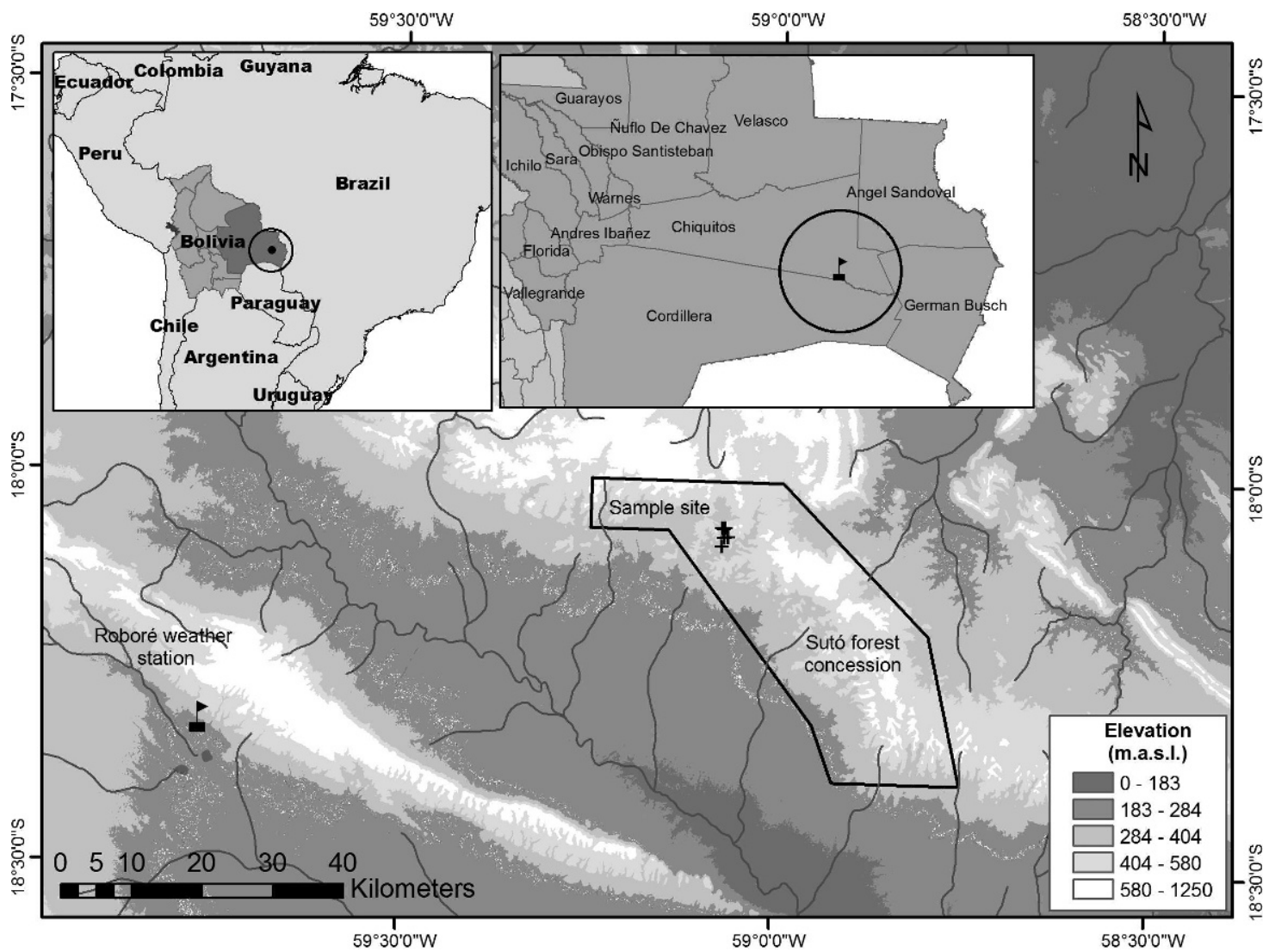

Figure 1. Sampling site in Sutó forest concession, Chiquitos province (Santa Cruz, Bolivia).

the Brazilian-Paranense region of Western Cerrado Biogeographic Province and is covered by semideciduous Chiquitano forest, usually rich in lianas. The canopy is 16 to $22 \mathrm{~m}$ high on average, with Amburana cearensis, Machaerium scleroxylon, Anadenanthera colubrina, Schinopsis brasiliensis, Acosmium cardenasii and Astronium urundeuva as representative species of the Chiquitano forest (Navarro 2011).

The climate in this area is warm (infratropical) to hot tropical (thermo). Annual rainfall ranges from 651 to $2029 \mathrm{~mm}$, and it is mainly concentrated from November to April and with low rainfall from May to October. Annual averaged temperatures range from $12.8^{\circ} \mathrm{C}$ to $39.5^{\circ} \mathrm{C}$ (Navarro 2011). The nearest weather station is located in Roboré $\left(18^{\circ} 19^{\prime} \mathrm{S}, 59^{\circ} 46^{\prime} \mathrm{W}\right.$, altitude $277 \mathrm{~m}$ ) (Figure 1). It is approximately $75 \mathrm{~km}$ from the study site and belongs to the
Bolivian National Service of Meteorology and Hydrology (SENAMHI). We used climate data for two purposes: to quantify changes in climatic trends in the study area during the available time span, and to assess climate-growth relationships. The climate data set used for the study contained rainfall records from 1942 to 2010 and temperature from 1978 to 2010 . We calculated annual rainfall and temperature starting from October of the previous year (i.e. the beginning of the rainy season and flowering of morado) until September of the current year.

In addition, the study explored correlations of the response of growth ring widths to the ENSO signal, defined by the Southern Oscillation Index (SOI; Ropelewski and Jones 1987) and the Sea Surface Temperature Index for the Niño $1.2\left(0^{\circ}\right.$ $\left.10^{\circ} \mathrm{S}, 90^{\circ}-80^{\circ} \mathrm{W}\right)$ and Niño 3.4 regions $\left(5^{\circ} \mathrm{N}-5^{\circ} \mathrm{S}\right.$, $170^{\circ}-120^{\circ} \mathrm{W}$ ) (Trenberth and Stepaniak 2001). The 
time-series of these indices were obtained from the NOAA Climate Prediction Centre (http://www. cpc.ncep.noaa.gov/data/indices/index.html).

\section{Tree Species}

Machaerium scleroxylon (Fabaceae) is considered the most important logging species in the Chiquitano forest (Killeen et al. 1993). Dauber et al. (2003) found that this species has an overall average diameter increment of $0.237 \mathrm{~cm} \mathrm{year}^{-1}$. It is a semi-deciduous and partially shade tolerant species common in the dry forest of the Great Chiquitanía. It flowers from November to December and its seeds are wind-dispersed between June and August (Justiniano and Fredericksen 2000; Mostacedo et al. 2003). Morado is light demanding during its early years, but is more shade tolerant than pioneer species such as Centrolobium microchaete, Anadenanthera macrocarpa and others. Morado thrives in various soil conditions such as stony ground and slopes with rapid drainage (Lorenzi 1992). The sapwood is yellowish white, distinct from the black purple color of the heartwood. Its timber is considered of high density with ranges from 0.85 to $0.95 \mathrm{~g} \mathrm{~cm}^{-3}$ (Nisgoski 1999; Gutiérrez and Silva 2002; Roque et al. 2007).

\section{Field Sampling and Histological Analysis}

Several factors make it difficult to obtain samples for tree-ring analysis using traditional dendrochronological techniques in the dry tropics of South America (López 2003). Cross-sections of trees provide a larger field of observation, as it is much easier to delimit the annual growth increments in such samples than in cores. Based on these considerations, we collected ten wood discs (DBH range 13.5-53.4 cm) from the area of the logging company Sutó Ltd. $\left(18^{\circ} 45^{\prime} \mathrm{S}, 59^{\circ} 40^{\prime} \mathrm{W}\right)$ between the towns of Roboré and Santa Ana de Chiquitos (Figure 1). It was not feasible to sample a large number of trees, as is commonly done in dendrochronological studies (Fritts 1976), because of the limitations related to the activities of the logging company. The samples were taken at breast height $(1.30 \mathrm{~m})$ from randomly distributed trees of different diameters with dominant and/or co-dominant height in the forest canopy during harvesting activities.

There is little available information about the yearly phenology of morado. Therefore, according to the literature on others species (Wimmer 2002; Brienen and Zuidema 2005; Ferrero and Villalba 2009; López and Villalba 2011; López et al. 2013), prior to tree-ring identification, histological analysis of the samples was performed to identify the boundaries of the rings to facilitate identification with the naked eye (Figure 3A). The reagents used for staining tissues of anatomical slices for the analysis of tree rings were ethyl alcohol, sodium hypochlorite, astra blue, and safranin. Further, for the identification of tree rings in the heartwood and because of the wood's grain characteristics, after sanding, the sample discs were immersed in sodium hypochlorite for 12 hours (Figure 3B) to improve the transverse visibility of tree rings located in the heartwood.

\section{Dendrochronological Data Analysis}

Cross-sections were air dried and carefully polished with progressively finer sandpapers until tree rings were clearly visible. After this, we selected 3 radii on each discs using a stereomicroscope. This approach was taken because of the difficulty in identifying wedging of rings with the naked eye. Similarly, areas with reduced visibility of tree rings were moistened with water. Once tree rings were identified and dated, wedging and false rings were identified and analyzed by checking their length and characteristics in the entire contour of the discs (Figure 3C). For crossdating purposes, each annual tree ring was assigned to the year in which the growth season started (from October of the current year to September of the following year; Schulman 1956).

After the identification process, the last 68 rings of each radius were crossdated. Because of the difficulty in ring identification and pith rot, dating complete sections of discs from bark to pith was not possible. Ring widths were then measured using the LINTAB-TSAP ${ }^{\mathrm{TM}}$ measuring device (Rinntech, Heidelberg, Germany) with a $0.01 \mathrm{~mm}$ resolution. Also, dating and measurements were 
revised with WinDendro ${ }^{\mathrm{TM}}$ (Regents Instruments, Canada) with a $0.001 \mathrm{~mm}$ resolution.

The software COFECHA (Holmes 1983) was used to statistically check errors in visual crossdating and to obtain a synchronized master chronology. For each tree, the series of raw data were detrended and standardized using ARSTAN software (Cook and Holmes 1986). This was done in order to remove biological and geometrical trends (age and size related growth trends). A cubic smoothing spline was used with a 50\% frequency response cutoff of 25 years to maintain the high-to-medium frequency response to climatic variability (Cook and Peters 1981). Autoregressive modeling was performed on each detrended ringwidth series to remove most of the first-order autocorrelation, and the prewhitened series were finally averaged using a biweight robust mean to obtain residual chronology, which was used to assess growth-climate relationships (Monserud 1986). In order to assess the quality of tree-ring width series, dendrochronological statistics were calculated considering the common 1942-2009 interval (Fritts 1976). For each chronology, we computed (a) the first-order autocorrelation of raw tree-ring width data, a measure of the year-toyear growth similarity (AR1), (b) the mean sensitivity of residual chronologies, which measures the year-to-year variability in width of consecutive rings (MS), (c) the mean betweentrees correlation, which quantifies the similarity in residual width indices among trees $(r b t)$, and (d) the percentage of variance explained by the first principal component, which is an estimate of the common variability in growth indices among all trees (PC1). The chronology segment with Expressed Population Signal (EPS) values higher than 0.85 was regarded as reliable and used in further climate-growth analyses, where EPS is a measure of the statistical quality of the mean site chronology as compared with a perfect infinitely replicated chronology (Wigley et al. 1984).

\section{Minimum Logging Diameter (MLD) Estimation}

In order to assess the cumulative growth in the basal area and to remove the trend of decreasing ring width with increasing tree size, we converted radial increment into Basal Area Increment (BAI) for all the trees using the following formula:

$$
\mathrm{BAI}=\pi\left(R_{\mathrm{t}}^{2}-R_{\mathrm{t}-1}^{2}\right)
$$

where $R$ is the radius of the tree and $t$ is the year of tree-ring formation. In wood discs without pith, we estimated the missing rings using a geometrical method and taking into account the mean growth rate of the innermost rings dated in samples with pith. Based on the radial increments and BAI results, we estimated the MLD presented by tree cumulative DBH curves and the physiological age for each sampled tree (López et al. 2013). The purpose of this analysis was not to date each growth ring accurately but to cumulate ring-width data, beginning with the pith ring and ending with last complete ring formed before bark. The relationship between age and cumulative diameter for sampled trees was calculated from the three measured radii per tree, which were first doubled to estimate diameter. Such diameter increments were then cumulated from the pith to the bark ring (Stahle et al. 1999; Schöngart et al. 2007). In cases where the available cross-section did not extend to the pith, the true position of the pith ring and the width of the first growth rings had to be estimated from the curvature and growth rate of the innermost rings dated in samples with pith. The relation between cumulative diameter and age was adapted to sigmoidal regression model.

\section{Radial Growth-Climate Relationship}

To determine the influence of local and regional climatic variables (atmospheric circulation patterns and climatic variables, rainfall and temperature) in morado radial growth, we related the tree-ring width residual indexed chronology to monthly climate data. The relationships between interannual variations in morado growth index and climate were established using Pearson correlation coefficients and response functions (Fritts 1976; Holmes 1999). Response function coefficients were based on bootstrapped stepwise multiple regressions computed on the principal 
components of climatic variables (Fritts 1976) using the DendroClim 2002@ software (Biondi and Waikul 2004). The significance of correlations was evaluated at $95 \%$ confidence limits by establishing comparisons with bootstrapped regression coefficients. This method correlates variations in the tree-ring chronology with sequential monthly temperature and rainfall records. Considering that tree growth might be influenced by climate conditions during both current and previous years, this analysis includes climate variables for the current and previous year of tree-ring formation (Vaganov et al. 2006). Based on previous dendrochronological studies (Ferrero and Villalba 2009), growth index was compared with monthly climate series of temperatures and rainfall from January of the previous growing season to December of the year of tree-ring formation for the 1978-2009 period of common climatic data.

We used monthly values for ENSO and SOI indices to determine their associations with treering width indices and the influences on cumulative growth. We analyzed the correlation patterns between the growth index and monthly El NiñoSouthern Oscillation (ENSO) indices using two different regions in the Pacific Ocean: El Niño 1.2 and El Niño 3.4, and monthly values of the Southern Oscillation Index (SOI) for the 19782009 period.

\section{RESULTS}

\section{Climate Trends}

The climatic characteristics of the study area are presented in ombrothermic diagrams (Figure 2) prepared from the Roboré weather station with SENAMHI data for periods 1980-1995 and 1996-2009. It should be noted that the decrease in precipitation amount during the growing season was more intense in the latter period $(F=3.85$, $P<0.05)$. Over the last 14 years (1996-2009), the dry season has increased significantly in length (from June-August to June-September) whereas the rainy season has become shorter (from October-March to November-March) and rainfall in June has decreased. Moreover, there are slight fluctuations in temperature in Roboré, and the period of high temperatures coincides with the November to March rainy season.

There was high variability of rainfall during the period 1942-2009. There were also extreme years, with the highest rainfall recorded in 1978 and the driest period recorded in 2009. Rainfall showed a slight overall decline in the last decade, whereas the temperature increased between $1{ }^{\circ} \mathrm{C}$ to $2{ }^{\circ} \mathrm{C}$ from the mean in the period 1978-2009. Furthermore, we found a negative relationship between annual rainfall and mean annual temperature (Figure 2). Spring and summer rainfall values greatly influence the annual mean estimations. Although there was greater data stability in annual average temperatures during summer, maximum and minimum temperatures values showed major fluctuations during spring and autumn.

\section{Chronology}

Based on anatomical analysis and local climatic conditions (most species have growth and leaf fall when wet and dry periods, respectively, are present during each year), the wood structure of M. scleroxylon was characterized by tree rings defined by marginal parenchyma fine lines and diffuse pores (Figure 3A and $\mathrm{C}$ ). Furthermore, lenses and false and wedging rings were identified, generally located where deformation occurred or where the discs did not have a circular shape.

We analyzed a total of 30 radii, corresponding to 10 cross-sections of M. scleroxylon composed of 3 radii each. These radii covered the period 1913-2009, although for the present dendroclimatic study we worked from 1942 because of the availability of climate data and the difficulty in dating the rings before that year. Thus, we analyzed a total of 68 years of data.

The mean tree-ring width for the common period 1942-2009 was $1.43 \mathrm{~mm}$. The first-order autocorrelation (AR1) of the tree-ring width series was 0.25 , suggesting a low year-to-year persistence in growth, whereas the mean sensitivity (MS) was 0.67 , indicating a higher inter-annual variability of radial growth (Table 1). The mean correlation between trees $(r b t)$ was 0.47 and the Expressed 

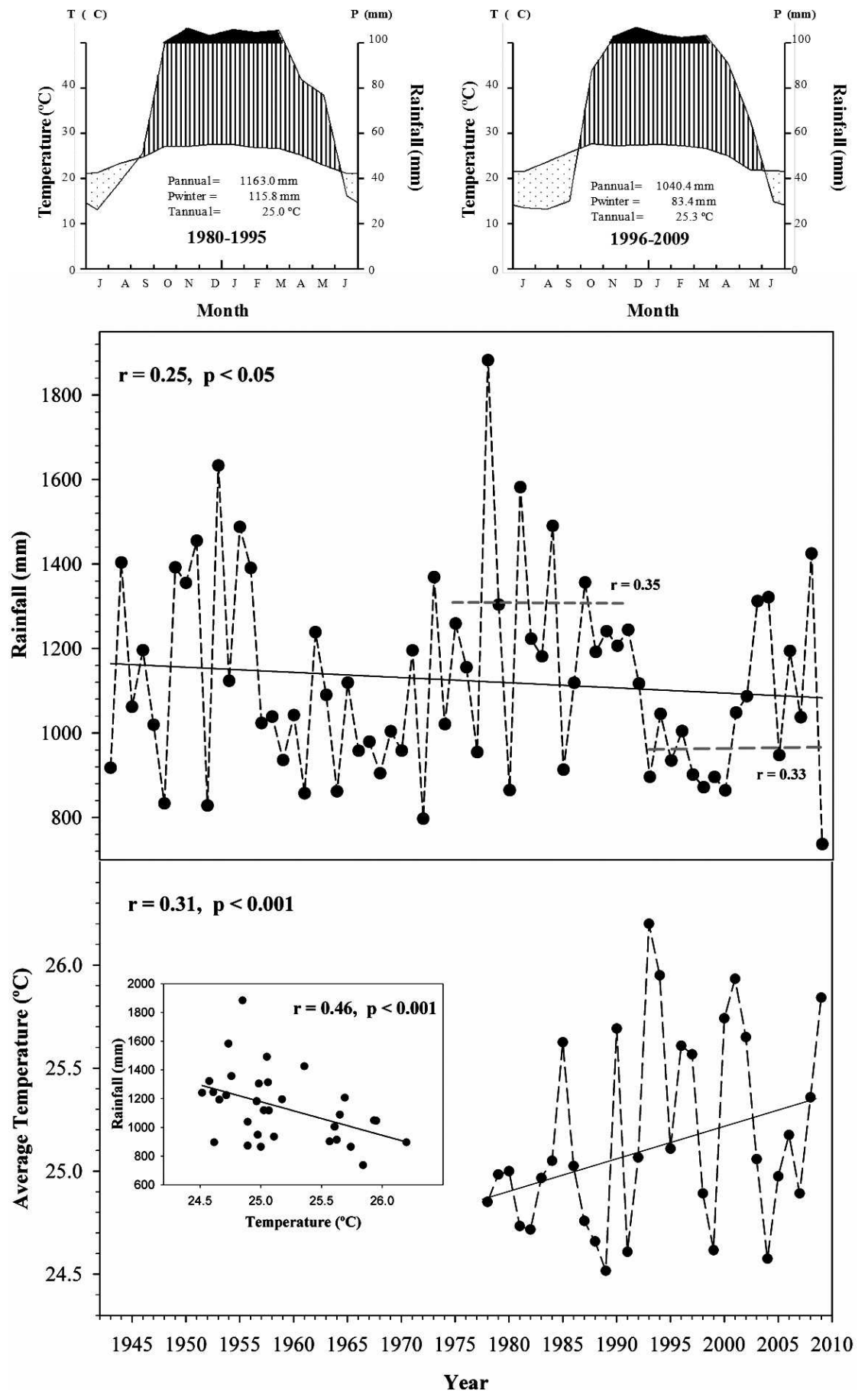

Figure 2. Ombrothermic diagrams (top) from the Roboré region for the periods 1980-1995 and 1996-2009 according to the SENAMHI database and climatic trends in mean annual rainfall for the period 1942-2009 (middle) and mean annual temperature for the years 1978-2009 (bottom), as well as the relationship of temperature and rainfall in Roboré. 


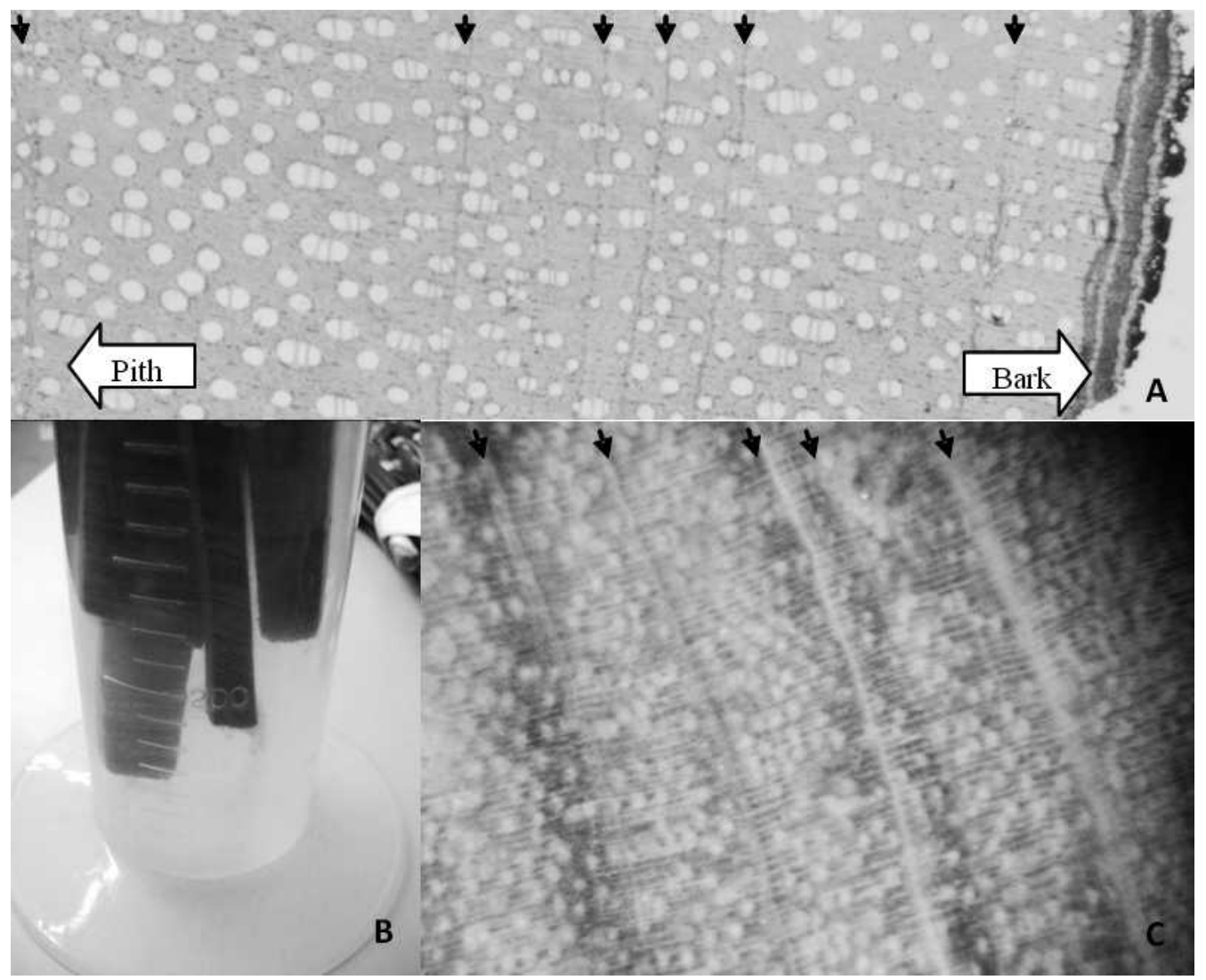

Figure 3. Visibility of tree rings after immersion in sodium hypochlorite. (A) Anatomical analysis and identification of tree rings. (B) Testing the effect of sodium hypochlorite in the samples. (C) Identification of rings in the heartwood after immersion.

Population Signal (EPS) was higher than 0.85 in the period 1942-2009, which show high growth consistency among trees, and that the number of samples collected and radii measured adequately represented the tree growth variability in the study area (Table 1).

We found a variation in growth, which suggested the existence of three significant stages or periods: 1942-1966, 1967-1982 and 1983-2009 (Figure 4A and B). During the period 1966-1988, growth increased and decreased by more than $1 \mathrm{~mm}$. The difference was more distinct for the period 1978-1982. The greatest growth took place during 1978.

We observed a direct relationship between water availability and growth in morado (Figure 4B), with

Table 1. Site description and characteristics of M. scleroxylon chronology in eastern Bolivia. The statistical values were calculated for the common period 1942-2009. All dendrochronological statistics were calculated for residual series excepting AR1, which was obtained for raw tree-ring width data. Values are expressed as means ( \pm 1 standard deviation).

\begin{tabular}{ccccccccc}
\hline Location & Dbh $(\mathrm{cm}) *$ & $\begin{array}{c}\text { Tree-ring } \\
\text { width }(\mathrm{mm})\end{array}$ & $\begin{array}{c}\text { Estimated } \\
\text { Age (years) }\end{array}$ & AR1 & rbt & MS & PC1 (\%) & EPS \\
\hline $\begin{array}{c}\text { Santa Ana- } \\
\text { Roboré }\end{array}$ & $39.0 \pm 14.6$ & $1.43 \pm 0.53$ & $120 \pm 35$ & $0.25 \pm 0.15$ & $0.47 \pm 0.11$ & $0.67 \pm 0.06$ & 45.73 & 0.930 \\
\hline
\end{tabular}

* Diameter at breast height measured at $1.3 \mathrm{~m}$; AR1 = first-order autocorrelation; $r b t=$ mean between-tree correlation; MS = mean sensitivity; PC1 = variance accounted for by the first principal component; EPS = Expressed Population Signal. 

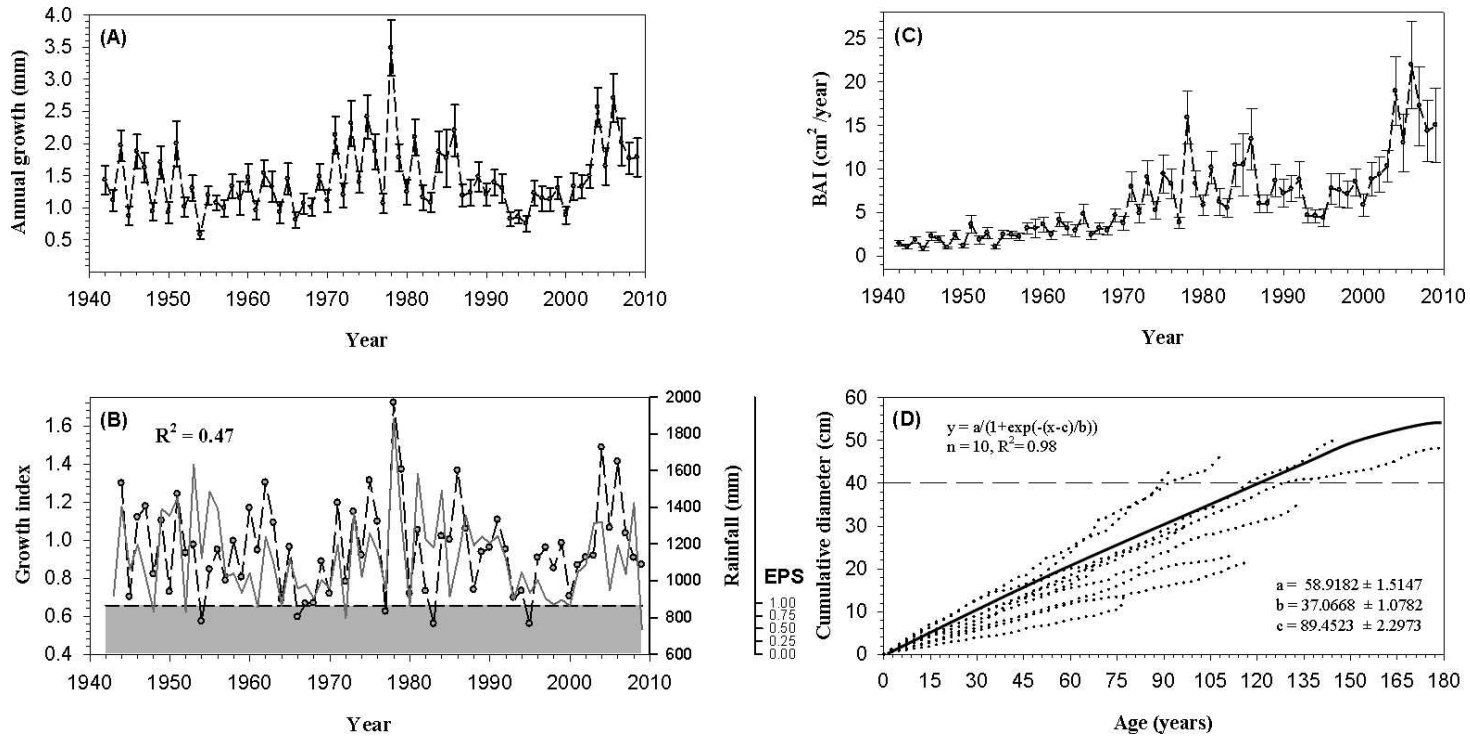

Figure 4. Radial growth changes in morado through the 1942-2009 period. Recent trend in (A) master chronology of ring width, (B) relationship of morado radial growth rate (black dotted line) and October-September local rainfall (gray solid line) during the growth period of the species and EPS statistics for morado chronology (the total interannual variation $\left(R^{2}\right)$ in the growth of morado explained by rainfall is indicated, (C) average basal area increment, and (D) relationship between physiological age and cumulative diameter for sampled trees, fitted with a sigmoidal regression model.

good synchrony between growth reductions and documented drought events in the study sites in 1954, 1977, 1983, 1995, 2000 and 2007. Similarly, positive growth coincided with observed wet years in 1951, 1963, 1978, 2004 and 2006 (Figure 4B). These positive growth levels mainly coincided with rainfall in December, January and February.

\section{Minimum Logging Diameter (MLD) Estimation}

The accumulated growth and Basal Area Increment showed an almost constant slope during the period 1940-1970, followed by relatively high growth, and finally a slight decrease starting from 1996 (Figure 4C). The Basal Area Increment showed a trend toward higher growth, which may indicate that the species has not reached its optimum production shift and requires a cutting cycle over 40 years, because the trend based on the adjusted sigmoidal regression equation remains positive after 140 years.

The average DBH of the morado population was $39 \mathrm{~cm}$, with 6 individuals exceeding the MLD of $40 \mathrm{~cm}$ established by the Bolivian Forestry Law No. 1700 (Table 1). The greatest contribution to total basal area was found at a $\mathrm{DBH}$ around $50 \mathrm{~cm}$. Estimated tree age of morado varied between 77 and 193 years (Figure 4D). The relationship between tree age and $\mathrm{DBH}$ of morado is statistically significant $\left(\mathrm{R}^{2}=0.98, P<0.001\right)$, allowing the modeling of cumulative diameter growth curves described by a sigmoidal regression model where $y$ is the cumulative diameter $(\mathrm{cm})$ and $x$ the tree age in years (Figure 4D). After 140 years, an average tree reaches approximately $50 \mathrm{~cm}$ of DBH. From the mean diameter growth curve we derived the current and mean diameter increment. Trees reach their maximum current diameter increments at an age of 70-86 years, with a rate averaging $0.83 \mathrm{~cm}$ year $^{-1}$, although the highest increment rate observed exceeded $1.49 \mathrm{~cm}_{\text {year }}{ }^{-1}$.

\section{Climate-Growth Relationship}

We found a significant correlation between growth and rainfall during previous January $(\mathrm{r}=$ 0.32 ), and non-significant but high correlation with previous September $(r=0.24)$ and the current January $(r=0.29)$ for the period 19782009. This was consistent with the rainy season, 


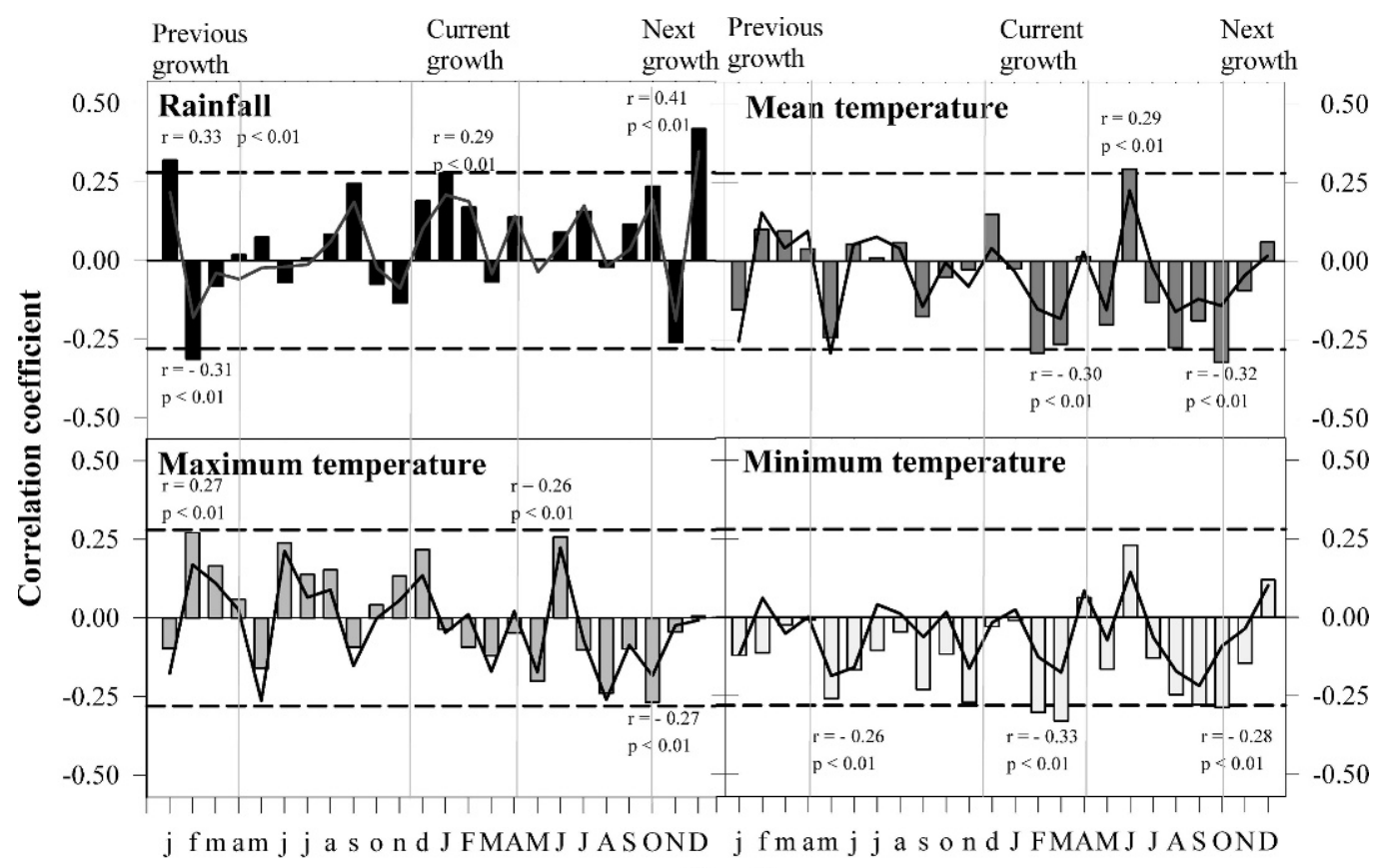

Month

Figure 5. Correlation (bars) and bootstrapped response coefficients (lines) between monthly climate variables and radial growth of morado (residual indices of ring width) during the common period 1978-2009 for rainfall and mean, maximum and minimum temperatures. Growth was correlated with climatic variables of previous year (months abbreviated in lowercase) and current or ringformation year (months abbreviated in capital letters). The horizontal dashed lines indicate significance at $\mathrm{p}<0.05$ and describes the $\mathrm{r}$ and $\mathrm{p}$ values for those with $\mathrm{r}>0.25$.

which provided support for a strong relationship between morado growth and late spring-summer rainfall in the semi-arid region of Chiquitanía. We found negative correlations with both mean and minimum temperatures in current February $(\mathrm{r}=$ $-0.30, \mathrm{r}=-0.31$, respectively) and March $(\mathrm{r}=$ $-0.26, \mathrm{r}=-0.33$, respectively). Maximum temperatures showed a significant positive correlation with previous February $(r=0.27)$ and the current June $(r$ $=0.26$ ), and significant negative correlation with the current October $(\mathrm{r}=-0.27)$ for the common period 1978-2009 (Figure 5). Above-average temperatures in spring and summer seem to have increased water deficit, reducing tree growth.

The chronology of M. scleroxylon showed a positive correlation with El Niño-Southern Oscillation (ENSO) (Figure 6). Specifically, the chronology response to SOI indices was generally positive throughout the growing season, showing the highest correlation in previous July $(\mathrm{r}=0.43)$
(Figure 6A). In contrast, the response to E1 Niño 3.4 and El Niño 1.2 regions for the ENSO in the Pacific Ocean was negative overall. El Niño 3.4 showed a significant negative correlation at the end of the growing season during the previous July ( $\mathrm{r}=$ -0.27 ) and a significant positive correlation during current September $(\mathrm{r}=0.33)$. El Niño 1.2 showed extreme negative values during October $(\mathrm{r}=-0.31)$ and April $(\mathrm{r}=-0.27)$ of the growing season (Figure 6B and C). Additionally, if we compare the behavior of SOI with the rainfall and growth shown in Figure 2 and Figure 4, respectively, El Niño affects the growth of the species in 1951-1952, 1963-1964, 1977-1978, 1986-1988, 2004-2005 and 2006-2007 when the thickness of the rings was greater than in other years. Similarly, reduced growth in years 1954 1956, 1964-1965, 1989-1990, 1999-2000 and 20072008 remarkably corresponds to La Niña (Figure 4). This behavior could be also explained for the relation between SOI and winter rainfall (dry season). 


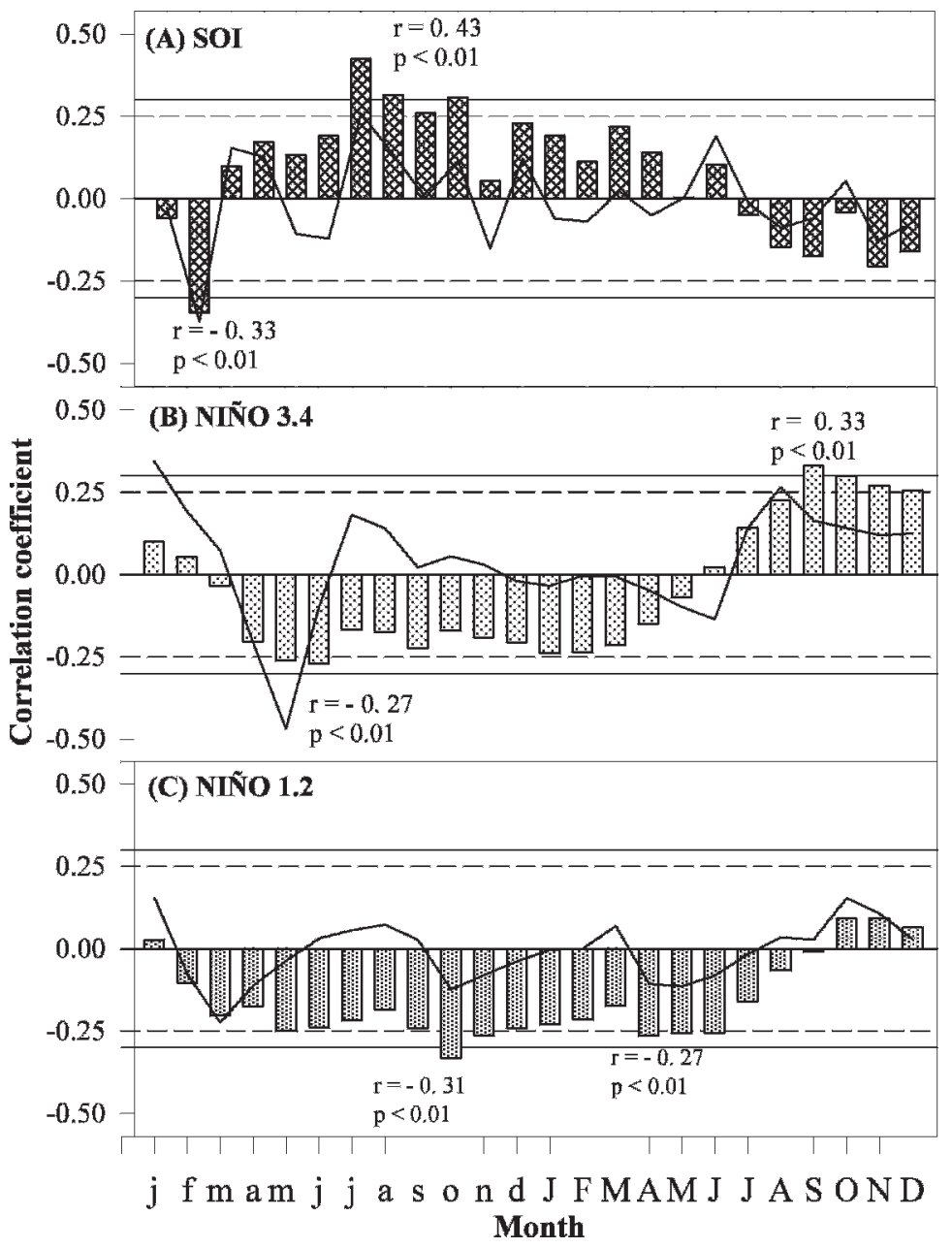

Figure 6. Correlations functions (bars) and bootstrapped response coefficients (lines) between (A) SOI, (B) El Niño 1.2 and (C) El Niño 3.4 global climate variables and morado radial growth (growth residual indices) during the common period 1978-2009. Growth was correlated with climatic variables of previous year (months abbreviated in lowercase) and current or ring formation year (months abbreviated in capital letters). The horizontal lines indicate the level of significance (dashed for bars, $\mathrm{p}<0.05$; solid for lines, $\mathrm{p}<0.01$ ) and describe the $\mathrm{r}$ and $\mathrm{p}$ values for those with $\mathrm{r}>0.25$.

\section{DISCUSSION}

Tree rings of $M$. scleroxylon (morado) have fine marginal parenchyma lines, which facilitated the identification of their boundaries although this species forms hardly distinguishable tree rings (Roig 2000). During the analysis of morado tree rings, we found lenses and false rings. Lenses are known as growth in certain sectors of the circumference of a tree caused by stimulus in cambial activity and/or vascular growth during the annual cycle (Villalba 1997; López 2003). We also found a high occurrence of wedging rings, which hampered the identification and measurement of tree rings (López 2003). The wedging rings were found in places of buttress formation on the trunk. Still, there was a significant correlation among the radii of a single tree but not between different trees; therefore we used three radii to reflect the geometry in each of them. Morado is considered of semideciduous habit, and because the existence of annual rings is more common in deciduous species than those in semideciduous or evergreen species (Borchert 1999; Worbes 1999), the intermediate 
characteristic that morado presented, both in dominance in the forest and abscission of leaves, may have affected the formation and growth of tree rings and consequently the correlation between them and climate during some periods.

We developed the first tree-ring chronology of morado, an important timber species from the lowland tropical dry forests in Bolivia. According to our results, morado tree rings are annual in nature. Statistics commonly used in tree-ring studies show a strong common signal between the individual series of the chronology. Additionally, analysis revealed the approximate age of $M$. scleroxylon trees, which mostly comprised $30 \%$ $70 \%$ of the dated radii from bark to pith. Thus, this species may have a long lifespan, with approximately 140 years at $50 \mathrm{~cm}$ of $\mathrm{DBH}$, which suggests the possibility of constructing longer series and chronologies.

Our results agree with previous dendroecological research on Bolivian forests (López and Villalba 2011; López et al. 2013). We found a close relationship between interannual variations in tree growth and local-regional climate. The water availability effect on the seasonal development of apical growth/leaf, flowering and cambial activity (Borchert 1994), driven by alternating periods of dry and rainy seasons in deciduous tree species, is an important factor for the formation of marginal parenchyma bands that delimit the growth rings in this species. Unfavorable climate conditions result in partial cambial activity and growth (Kozlowski 1971) and even complete cambial dormancy, especially when there are dry periods of at least two months with rainfall below $50 \mathrm{~mm}$ (Worbes 1999). The seasonality in rainfall delimits ring growth (Eckstein et al. 1981; Jacoby 1989).

In the studied area, temperature rose and precipitation decreased, particularly in the growing seasons, during the second half of the $20^{\text {th }}$ Century, showing a trend towards aridification since the 1970s as observed in other forested sites in Bolivia (Brienen and Zuidema 2006a; López and Villalba 2011). Over the last decade, it has been widely observed that tree rings are formed annually in tropical forest with rainfall seasonality (Stahle et al. 1999; Worbes 1999, 2002; Dunisch et al. 2002; Fichtler et al. 2003; Brienen and Zuidema
2005; Ferrero and Villalba 2009). We propose that morado has annual ring formation based in the tree-ring structure described, considering marginal parenchyma as the main trait to define ring boundaries. The high correlation values obtained between growth and annual climatic parameters strongly supports our hypothesis (see Figure 4B and 5). The negative correlation of growthtemperature when growth is positively correlated to rainfall appears to be related to the seasonal rainfall distribution and to morado phenology. We also found that the dry season has apparently become longer and more intense over the last 14 years in Roboré (Figure 2), and it is related to changes in El Niño-Southern Oscillation (Figure 3).

We found a high correlation between morado radial growth and rainfall during December, January and February, corresponding to the rainy season. Soriano (2005) also found a high positive correlation between rainfall and reproductive period in $M$. scleroxylon, confirming the relationship between diameter growth and rainfall during the current and previous year of tree-ring formation found in this study (Figure 5). In contrast, we found a negative correlation between growth and temperature during the growing season, thus demonstrating the connection to radial growth. Interannual variation in tree growth is directly related to water supply (i.e. the balance between rainfall and evapotranspiration, which in turn is largely regulated by temperature) (López and Villalba 2011).

High summer temperatures inhibit tree growth because of water deficit (Ferrero and Villalba 2009), as water resources act as a limiting factor of growth (Borchert 1994, 1999; Toledo et al. 2011). Our results are consistent with those found in Centrolobium microchaete (López and Villalba 2011) in which growth appears to be favored by abundant rainfall in combination with lower-than-average temperatures during late spring and early summer. Also, Swietenia macrophylla in the Amazon has shown a strong correlation between changes in rainfall and growth from November to January (Dunisch et al. 2003).

The results of this study, through analysis of tree-ring growth and climatic fluctuations, show 
the effect of ENSO on the local climate, which in turn influences the annual growth variability of the species expressed in their diametric development. Therefore, we obtained a high correlation between SOI events and M. scleroxylon chronology. SOI fluctuations appear to have great influence in the growing season of this species and the dry periods of our study area, showing a negative correlation with El Niño 3.4 and El Niño 1.2 (negative phase of SOI) at the end of the growing season. In a broader context, we observe the effect of El Niño on regional rainfall behavior (with high rainfall events including flooding in the study area) and in morado growth during specific years 1951-1952, 1963-1964, 1977-1978, 19861988, 2004-2005 and 2006-2007, and the effect of La Niña during the very dry years 1954-1956, 1964-1965, 1989-1990, 1999-2000 and 2007-2008. These results confirm that the effects of atmospheric circulation patterns on morado growth in the study area are probably an indirect expression of their effects on local precipitation conditions and drought regimes.

Additionally, there are many conditions affecting not only the formation (growth activation) of rings but also their width. The ring-width series also reflect a complex set of variations in tree growth affected by a wide range of nonclimatic factors (Brookhouse 2006). For example, light availability is one of the most important factors for growth and establishment of many tree species in the dry forest of Chiquitanía, where most species are codominant in relation to the position of the tree canopy (Killeen et al. 1998). Therefore, the codominant nature of morado in the Chiquitano forest may explain certain periods of negative correlation between ring width and climate. Another factor related to morado-treegrowth is the presence of lianas (Putz 1991). It was found that tropical dry forests in Bolivia have about $75 \%$ and $77 \%$ infestation of lianas (Carse et al. 2000; Uslar et al. 2003), which was confirmed in a further regional comparative analysis, with $50 \%-80 \%$ of liana infestation in dry forests and percentages below $50 \%$ in tropical rainforests in northern Bolivia (Toledo et al. 2008). In addition to this, recent studies in South America have found that the presence of lianas has increased because of climate change (Phillips et al. 2002; van der Heijden and Phillips 2009). Despite the possible effect of insolation, lianas, and competition on growth, rainfall has been found to be a very important factor in most cases. Toledo et al. (2011) concluded that climate and water availability are strong factors that determine variations in growth rates in different types of forests in Bolivia. According to Markesteijn et al. (2010), the surface of the dry forest soil is drier than deeper layers during the dry season, being opposite in the wet season. In addition, climatic and edaphic factors are correlated and species can coexist in areas with topographical differences, drawing water from different soil layers and/or doing so in different seasons.

Regarding the estimation of MLD, several authors have found that the diameter is a poor indicator of tree age (Harper 1977; Sarukhan et al. 1984; Stahle et al. 1999). Some studies have used radial-growth averages to eliminate bias caused by age-related long-term size and variations of shortterm growth caused by climate (Nowacki and Abrams 1997), but for growth-rate analysis purposes, the use of the mean or median tends to overestimate the age of trees (Brienen and Zuidema 2006a). It has been estimated that M. scleroxylon has a general average diameter increment of $2.86 \mathrm{~mm}$ year $^{-1}$ (Dauber et al. 2003), and according to the results obtained, the species had an annual increase of $1.43 \mathrm{~mm}$ year ${ }^{-1}$ with high variations in growth during the period 1913-2009, which are probably caused mostly by variations in climate (rainfall and temperature). A similar result, using tree-ring analysis, was found in C. microchaete (López and Villalba 2011) for the Chiquitanía region (Concepción), with an average annual increase of $1.80 \mathrm{~mm}$ year $^{-1}$. That raises concern about the general overestimation of species growth rates in the dry forest in the Bolivian Forestry Law and its consequence for management.

Our results provide interesting insight into the radial growth of morado in the Chiquitania region with important implications for timber management (Figure 4D). The growth rate was quite slow in trees studied, which makes us question the MLD recommended for this species. The minimum harvestable size of morado in 
Chiquitano forests is $40-\mathrm{cm}$ diameter at breast height $(\mathrm{DBH})$ with a minimum cutting cycle (20 years) recommended by the Technical Standards of the Forestry Act No. 1700 in Bolivia (MDSP 1998). The power functions to the cumulative diameters indicate that on average it will take an estimated 122 years beyond the suffrutex stage to achieve this harvestable size for the ten sampled morado trees. These results suggest that the arbitrary $40-\mathrm{cm}$ DBH minimum size requires a long rotation period but bears little relation to the age structure or stand dynamics of forests in Santa Cruz Region (Brienen and Zuidema 2006b; López et al. 2013). There is also an appreciable variability in the growth rate of sampled trees, but based on our results the optimal period to harvest the trees is at the peak of the current volume increment, when morado trees have a biological rotation age greater than 140 years (Schöngart et al. 2007; López et al. 2013). Tree diameter at the maximum current volume increment seems to indicate the preferred time for logging. In this species, based on the diameter growth model (Figure 4D), this corresponds to a DBH of $50 \mathrm{~cm}$, which seems to be an appropriate MLD (Stahle et al. 1999; Brienen and Zuidema 2006b). The cutting cycle, calculated from the mean passage of time through $10 \mathrm{~cm}$ DBH classes until the tree reaches the MLD of $50 \mathrm{~cm}$ (Figure 4D), is approximately 40 years depending on each individual tree (Brienen and Zuidema 2006a, 2006b; López et al. 2012, 2013).

Furthermore, it is noteworthy that the productivity of seeds in $M$. scleroxylon remains high in trees of $100-\mathrm{cm}$ DBH (Soriano 2005). Both seed productivity and positive growth in diameters greater than $40 \mathrm{~cm}$ indicate that a greater MLD should be considered in forest management plans for this species. Similar results have been found in Amburana cearensis, Anadenanthera colubrina, Platimiscium ulei, Ficus boliviana, Hymenaea courbaril and Cedrela fissilis in the Chiquitano and Guarayos regions, respectively (López et al. 2012, 2013). However, silvicultural treatment applications and pith rot in trees should also be reviewed before determining the MLD. Our results suggest that careful studies of tree age, size, and environmental conditions could produce useful volume and yield tables for the species' ecological settings, and may lead to improved management of this important species. It should be noted that the results of this study are based on the mean diameters of the samples of different sizes, without pith dating because of rot area observed in many of the M. scleroxylon trees in this study $(60 \%$ of samples), but can be useful to provide an idea of morado growth and behavior.

\section{CONCLUSIONS}

In southeastern Chiquitano forests, annual temperature has increased and the rainfall in the rainy season has decreased during the $20^{\text {th }}$ Century, leading to a long-term reduction in water availability, which is expressed in tree-ring width related to radial growth. Because of the seasonality of the study area, in which leaf senescence and growth significantly correlate with rainfall, the rings of M. scleroxylon are considered to form annually. Rainfall was the most influential climatic variable on radial growth, confirming that water availability is a limiting factor for this growth. We found a significant positive correlation between rainfall and growth during January of the previous year and December, January and February of the year of ring formation, which corresponds to the rainy season. Moreover, temperature had a negatively correlation for those months, which seems consistent with the growth inhibition associated with drought stress and atmospheric pressure indexes such as SOI. El Niño-Southern Oscillation (ENSO) also showed a positive correlation with the chronology constructed, which was also positively correlated with SOI indices but negatively correlated with El Niño 3.4 and El Niño 1.2 throughout the growing season. However, despite the significant correlation of these variables, there are periods still seemingly affected by other factors such as light availability, competition and lianas, which requires a more comprehensive analysis on the effect of ENSO on M. scleroxylon growth.

In addition, wedging rings, false rings and lenses in morado seem to be the result of climatic and non-climatic variables, which were a challenge for the identification and measurement of morado 
tree rings. To resolve these problems, alternative techniques were used, such as immersion of the discs in sodium hypochlorite. Based on the available data, the number of samples taken and the variety of selected sizes, we suggest that growth and diameter increment of morado remain positive in trees older than 140 years and MLD around $50 \mathrm{~cm}$, but with low growth rates in small-diameter trees. Therefore, despite the limited number of samples analyzed, our findings indicate an optimal cutting cycle higher than 40 years. To improve this understanding, future studies should include phenological analysis and repeated sampling of cambial activity and xylem formation in morado.

\section{ACKNOWLEDGMENTS}

This study was funded by the Forest Advanced Technology Center (CTAF/UCO/UAGRM). The authors wish to thank the following individuals and organizations: Sutó Company for providing samples and for their support during the fieldwork of this study; the Bolivian National Service of Meteorology and Hydrology (SENAMHI), which provided the climate record; Rebecca Franklin from the Laboratory of Tree-Ring Research in Arizona, Guillermo Guada from University of Cordoba and Julio J. Camarero and his team at the Pyrenean Institute of Ecology-CSIC in Zaragoza for the support during the extraction and histological analysis of our samples; Peter van der Sleen for his ongoing support and useful discussions; Thomas W. Swetnam, Rex Adams, Chris Baisan, Paul Sheppard and Steve Leavitt from the Laboratory of Tree-Ring Research, whose discussions dispelled many doubts during the learning process of Dendrochronology. R. Sánchez-Salguero thanks the support of the FPU grant (AP2007-04747, MCI, Spain). We thank the editor and two referees for their valuable comments to improve the manuscript.

\section{REFERENCES CITED}

Biondi, F., and K. Waikul, 2004. DENDROCLIM2002: A C++ program for statistical calibration of climate signals in treering chronologies. Computers \& Geosciences 30:303-311.

Borchert, R., 1994. Water storage in soil or tree stems determines phenology and distribution of tropical dry forest trees. Ecology 75:1437-1449.
Borchert, R., 1999. Climatic periodicity, phenology and cambium activity in tropical dry forest trees. IAWA Journal 20(3):239-247.

Brienen, R. J. W., 2005. Tree Rings in the Tropics: A Study on Growth and Ages of Bolivian Rain Forest Trees. PROMAB Scientific Series 10, Riberalta, Bolivia.

Brienen, R. J. W., and P. A. Zuidema, 2005. Relating tree growth to rainfall in Bolivian rain forest: A test for six species using tree ring analysis. Oecologia 146:1-12.

Brienen, R. J. W., and P. A. Zuidema, 2006a. Lifetime growth patterns and ages of Bolivian rain forest trees obtained by tree ring analysis. Journal of Ecology 94:481-493.

Brienen, R. J. W., and P. A. Zuidema, 2006b. The use of tree rings in tropical forest management: Projecting timber yields of four Bolivian tree species. Forest Ecology and Management 226:256-267.

Brookhouse, M., 2006. Eucalypt dendrochronology: Past, present and potential. Australian Journal of Botany 54:435-449.

Carse, L. E., T. S. Fredericksen, and J. C. Licona, 2000. Lianatree species associations in a Bolivian dry forest. Tropical Ecology 41:1-10.

Cook, E. R., 1992. Using tree rings to study past El Niño/ southern Oscillation influences on climate. In El Niño: Historical and Paleoclimatic Aspects of the Southern Oscillation, edited by F. H. Diaz, and V. Markgraf, pp. 203-214. Cambridge University Press, New York.

Cook, E. R., and R. L. Holmes, 1986. Users' manual for program ARSTAN. Laboratory of Tree-Ring Research, University of Arizona. Tucson, Arizona

Cook, E. R., and K. Peters, 1981. The smoothing spline: A new approach to standardizing forest interior ring-width series for dendroclimatic studies. Tree-Ring Bulletin 41:45-53.

Dauber, E., T. Fredericksen, M. Peña-Claros, C. Leaño, J. C. Licona, and F. Contreras, 2003. Tasas de Incremento Diamétrico, Mortalidad y Reclutamiento con Base en las Parcelas Permanentes Instaladas en Diferentes Regiones de Bolivia. Proyecto de Manejo Forestal Sostenible BOLFOR, Santa Cruz, Bolivia.

Dunisch, O., J. Bauch, and L. Gasparotto, 2002. Formation of increment zones and intraannual growth dynamics in the xylem of Swietenia macrophylla, Carapa guianensis, and Cedrela odorata (Meliaceae). IAWA Journal 23:101-119.

Dunisch, O., V. Ribeiro Montóia, and J. Bauch, 2003. Dendroecological investigations on Swietenia macrophylla King and Cedrela odorata L. (Meliaceae) in the central Amazon. Trees 17:244-250.

Eckstein, D., J. Ogden, C. G. Jacoby, and J. Ash, 1981. Age and growth rate determination in tropical trees: The application of dendrochronological methods. In Age and Growth Rate of Tropical Trees: New Directions for Research, edited by F. H. Bormanm, and G. Berlyn, pp. 83-106. Bulletin 94. Connecticut Yale University, School of Forestry and Environment Studies.

Ferrero, M. E., and R. Villalba, 2009. Potential of Schinopsis lorentzii for dendrochronological studies in subtropical dry Chaco forests of South America. Trees 23:1275-1284.

Fichtler, E., D. A. Clark, and M. Worbes, 2003. Age and longterm growth of trees in an old-growth tropical rain forest, based on analyses of tree rings and C-14. Biotropica 35: 306-317. 
Fritts, H. C., 1976. Tree Rings and Climate. Academic Press, London.

García-Fernández, C., P. Sist, and M. Kanashiro, 2007. Manejo sostenible de los bosques tropicales desafíos para las prácticas de aprovechamiento de impacto reducido. Recursos Naturales y Ambiente 49-50:12-17.

Gutiérrez, V., and J. Silva, 2002. Información Técnica para el Procesamiento Industrial de 134 Especies Maderables de Bolivia. Serie técnica XII. Instituto Brasileiro do Medio Ambiente e dos Recursos Naturais Renováveis IBAMA, ATP FAO-PAFBOL, 371 pp.

Harper, J. L., 1977. Population Biology of Plants. Academic Press, Nueva York.

Holmes, R. L., 1983. Computer-assisted quality control in treering dating and measurement. Tree-Ring Bulletin 43:69-75.

Holmes, R. L., 1999. Dendrochronology Program Library (DPL) Users Manual. Laboratory of Tree-Ring Research, University of Arizona, Tucson.

Jacoby, G. C., 1989. Overview of tree-ring analysis in tropical regions. IAWA Bulletin 10(92):99-108.

Jagels, R., J. Hornbeck, and S. Marden, 1994. Drought and Cold Stress-Induced Morphometric Changes in Tree Rings of Red Spruce. Technical Bulletin, Maine Agricultural and Forest Experiment Station; 19 pp.

Justiniano, M. J., and T. Fredericksen, 1998. Ecología y Silvicultura de Especies Menos Conocidas - Morado, Machaerium scleroxylon Tul., Fabaceae. Proyecto de Manejo Forestal Sostenible BOLFOR, Santa Cruz, Bolivia; 21 pp.

Justiniano, M. J., and T. Fredericksen, 2000. Phenology of tree species in Bolivian dry forests. Biotropica 32(2):276-281.

Killeen, T., S. Beck, and E. García, 1993. Guía de Árboles de Bolivia. Herbario Nacional de Bolivia and Missouri Botanical Garden, La Paz, Bolivia; pp. 140-142.

Killeen, T. J., A. Jardim, F. Mamani, and N. Rojas, 1998. Diversity, composition and structure of a tropical semideciduous forest in the Chiquitania region of Santa Cruz, Bolivia. Journal of Tropical Ecology 14:803-827.

Kozlowski, T. T., 1971. Growth and Development of Trees. Volume II. Cambial growth, root growth and reproductive growth. Academic Press Inc., New York, USA.

López, L., 2003. Estudio de Anillos de Crecimiento en Once Especies Forestales de Santa Cruz-Bolivia. Thesis, Universidad Autónoma Gabriel René Moreno, Santa Cruz, Bolivia; $85 \mathrm{pp}$.

López, L., and R. Villalba, 2011. Climate influences on the radial growth of Centrolobium microchaete, a valuable timber species from the tropical dry forests in Bolivia. Biotropica 43(1):41-49.

López, L., R. Villalba, and F. Bravo, 2013. Cumulative diameter growth and biological rotation age for seven tree species in the Cerrado biogeographical province of Bolivia. Forest Ecology and Management 292:49-55.

López, L., R. Villalba, and M. Peña-Claros, 2012. Ritmos de crecimiento diamétrico en los bosques secos tropicales: aportes al manejo sostenible de los bosques de la provincia biogeográfica del Cerrado Boliviano. Bosque 33(2):211-219.

Lorenzi, H., 1992. Arvores Brasileiras. Editorial Plantarum Ltda, Sao Paulo, Brasil.
Markesteijn, L., J. Iraipi, F. Bongers, and L. Poorter, 2010 Seasonal variation in soil and plant water potentials in a Bolivian tropical moist and dry forest. Journal of Tropical Ecology 26:497-508.

Ministerio de Desarrollo Sostenible y Planificación (MDSP), 1998. Normas Técnicas para la Elaboración de Instrumentos de Manejo Forestal (Inventarios, Planes de Manejo, Planes Operativos, Mapas) en Propiedades Privadas o Concesiones con Superficies Mayores a 200 Hectáreas. Resolución Ministerial No 248/98, Ministerio de Desarrollo Sostenible y Planificación, La Paz, Bolivia.

Monserud, R. A., 1986. Time-series analyses of tree-ring chronologies. Forest Science 32:349-372.

Mostacedo, B., J. Justiniano, M. Toledo, and T. Fredericksen, 2003. Guía Dendrológica de Especies Forestales de Bolivia. BOLFOR/IBIF, Editorial El País, Santa Cruz, Bolivia.

Navarro, G., 2011. Clasificación de la Vegetación de Bolivia. Centro de Ecología Difusión Simón I. Patiño, Santa Cruz, Bolivia.

Nisgoski, S., 1999. Identificação e Caracterização Macroscópica das Principais Espécies Utilizadas para Laminação na Região de Curitiba-Pr. M.S. thesis, Universidade Federal do Paraná, Curitiba; 101 pp.

NOAA/National Weather Service, 2005. El Niño Regions. National Centers for Environmental Prediction, Climate Prediction Center, Maryland, USA. (http://www.cpc.ncep.noaa. gov/products/analysis_monitoring/ensostuff/nino_regions. shtml)

Nowacki, G. J., and M. D. Abrams, 1997. Radial-growth averaging criteria for reconstructing disturbance histories from presettlement-origin oaks. Ecological Monographs 67: 225-249.

Parker, T. A., A. H. Gentry, R. B. Foster, L. H. Emmons, and J. V. Remsen, 1993. The Lowland Dry Forests of Santa Cruz, Bolivia: A Global Conservation Priority. Conservation International, Rapid Assessment Program Working Paper 5, Washington, D. C.

Phillips, O. L., R. Vásquez Martínez, L. Arroyo, T. R. Baker, T. J. Killeen, S. L. Lewis, Y. Malhi, A. Monteagudo, D. A. Neill, P. Núñez Vargas, M. Alexiades, C. Cerón, A. Di Fiore, T. Erwin, A. Jardim, W. Palacios, M. Saldias, and B. Vinceti, 2002. Increasing dominance of large lianas in Amazonian forests. Nature 418:770-774.

Pumijumnong, N., 1999. Climate-growth relationships of teak (Tectona grandis L.) from Northern Thailand. In Tree Ring Analysis: Biological, Methodological and Environmental Aspects, edited by R. E. Vetter, and R. Wimmer, pp. 155-168. CAB International, Wallingford, Oxon, UK.

Pumijumnong, N., and W. Park, 1999. Vessel chronologies from teak in Northern Thailand and their climatic signal. IAWA Journal 20(3):285-294.

Putz, F., 1991. Silvicultural effects of lianas. In Biology of Vines, edited by H. A. Mooney, pp. 493-501. Cambridge University Press, Cambridge, UK.

Roig, F. A., 2000. Dendrocronología en los bosques del Neotrópico: revisión y prospección futura. In Dendrocronología en América Latina, edited by F. A. Roig, pp. 307-357. Editorial de la Universidad Nacional de Cuyo, Mendoza, Argentina. 
Ropelewski, C. F., and P. D. Jones, 1987. An extension of the Tahiti-Darwin Southern Oscillation Index. Monthly Weather Review 115:2161-2165.

Roque, R., M. Gómez, and J. Rivero, 2007. Clave de identificación macroscópica para 22 especies maderables de Bolivia. Revista Forestal Venezolana 51(2):179-193.

Rozendaal, D., 2010. Looking backwards: using tree rings to evaluate long-term growth patterns of Bolivian forest trees. PROMAB Scientific Series 12, Riberalta, Bolivia.

Sarukhan, J., M. Martinez-Ramos, and D. Pinero, 1984. The analysis of demographic variability at the individual level and its population consequences. In Perspectives on Population Ecology, edited by J. Sarukhan, and R. Dirzo, pp. 141-165. Sinauer Associates Inc., Sunderland, Massachusetts, USA.

Shortle, W. C., K. T. Smith, R. Minocha, V. A. Alexeyev, and P. Stott, 1995. Similar patterns of change in stem wood calcium concentration in red spruce and Siberian fir. Journal of Biogeography 22:467-473.

Schöngart, J., F. Wittmann, M. Worbes, M. T. F. Piedade, and W. J. Junk, 2007. Management criteria for Ficus insipid Willd. (Moraceae) in Amazonian white-water floodplain forests defined by tree-ring analysis. Annals of Forest Science 64:657-664.

Schulman, E., 1956. Dendroclimatic Changes in Semiarid America. University of Arizona Press, Tucson.

Soliz-Gamboa, C., D. Rozendaal, G. Ceccantini, V. Angyalossy, K. van der Borg, and P. Zuidema, 2011. Evaluating the annual nature of juvenile rings in Bolivian tropical rainforest trees. Trees - Structure and Function 25:17-27.

Soriano, M., 2005. Caracterización reproductiva y germinativa de especies forestales maderables en bosque seco Chiquitano en Santa Cruz, Bolivia. Thesis, Universidad Autónoma Gabriel René Moreno, Santa Cruz; 49 pp.

Stahle, D. W., P. T. Mushove, M. K. Cleaveland, F. A. Roig, and G. A. Haynes, 1999. Management implications of annual tree rings in Pterocarpus angolensis from Zimbabwe. Forest Ecology and Management 124:217-229.

Toledo, M., L. Poorter, M. Peña-Claros, A. Alarcón, J. Balcázar, C. Leaño, J. C. Licona, O. Llanque, V. Vroomans, P. Zuidema, and F. Bongers, 2011. Climate is a stronger driver of tree and forest growth rates than soil and disturbance. Journal of Ecology 99:254-264.

Toledo, M., L. Poorter, M. Peña-Claros, C. Leaño, and F. Bongers, 2008. Diferencias, en las características edáficas y la estructura del bosque, de cuatro ecoregiones forestales de Bolivia. ReBECA 24:11-26.
Tomazello, M., and N. da Silva Cardoso, 1999. Seasonal varations of the vascular cambium of Teak (Tectona grandis L.) in Brazil. In Tree-ring analysis. Biological, methodological and environmental aspects, edited by $\mathrm{R}$. Wimmer, and $\mathrm{R}$. Vetter, pp. 147-154. CAB Publishing, Oxon.

Trenberth, K. E., and D. P. Stepaniak, 2001. Indices of El Niño evolution. Journal of Climate 14:1697-1701.

Uslar, Y., B. Mostacedo, and M. Saldías, 2003. Composición, estructura y dinámica de un bosque seco semideciduo en Santa Cruz, Bolivia. Documento Técnico 114, Proyecto BOLFOR; 28 pp.

Vaganov, E. A., M. K. Hughes, and A. V. Shashkin, 2006. Growth Dynamics of Tree Rings: An Image of Past and Future Environments. Springer, New York.

Villalba, R., 1997. Curso de dendrocronología en las regiones tropicales, 14-25 de Abril. Inter-American Institute for Global Change Research (IAI), La Paz, Bolivia.

van der Heijden, G. M. F., and O. L. Phillips, 2009. Liana infestation impacts tree growth in a lowland tropical moist forest. Biogeosciences 6:2217-2226.

Weber, U. M., 1997. Dendroecological reconstruction and interpretation of Larch budmoth (Zeiraphera diniana) outbreaks in two central alpine valleys of Switzerland from 1470-1990. Trees: Structure and Function 11:277-290.

Wigley, T. M. L., K. R. Briffa, and P. D. Jones, 1984. On the average of correlated time series with applications in dendroclimatology and hydrometeorology. Journal of Climate and Applied Meteorology 23:201-213.

Wimmer, R., 2002. Wood anatomical features in tree-rings as indicators of environmental change. Dendrochronologia 20(1-2):21-36.

Worbes, M., 1992. Occurrence of seasonal climate and tree-ring research in the tropics. Lundqua Report 34:338-342.

Worbes, M., 1999. Annual growth rings, rainfall-dependent growth and long-term growth patterns of tropical trees from the Caparo Forest Reserve in Venezuela. Journal of Ecology 87:391-403.

Worbes, M., 2002. One hundred years of tree-ring research in the tropics: A brief history and an outlook to future challenges. Dendrochronologia 20:217-31.

Received 25 October 2012; accepted 16 June 2013. 